\title{
Torrefaction of Sorghum Biomass to Improve Fuel Properties
}

\author{
Yang Yue ${ }^{1}$, Hari Singh ${ }^{2}$ Bharat Singh $^{2}$ and Sudhagar Mani ${ }^{1 *}$, \\ ${ }^{1}$ BioChemical Engineering, College of Engineering, University of Georgia, Athens, GA \\ ${ }^{2}$ Plant Science, College of Agriculture, Family Sciences and Technology, Fort Valley State \\ University, Fort Valley, GA
}

\begin{abstract}
Torrefaction of energy sorghum and sweet sorghum bagasse was investigated at three different temperatures $\left(250,275 \& 300{ }^{\circ} \mathrm{C}\right)$ for $30 \mathrm{~min}$ to determine product yields and its compositions. The torrefied solid yield ranged from 43 to $65 \%$ for sweet sorghum bagasse and 51 to $70 \%$ for energy sorghum. The energy density of both torrefied sorghums increased between 1.6 and 1.4 folds. Besides water, the acetic acid, with a maximum yield of $101.90 \mathrm{~g} / \mathrm{L}$ was the dominant compound in the aqueous fraction of liquid products. The aqueous fraction from sweet sorghum bagasse contained furfural and furan carboxyl aldehydes, while ketones and alcohols were dominant from energy sorghum as other key compounds. Phenolic type chemicals and furan derivatives were the major compounds in the oil fraction of the liquid product, accounted up to $58 \mathrm{wt} \%$. The condensable liquid products can be further upgraded into high-value platform chemicals.
\end{abstract}

Keywords: torrefaction, sorghum biomass, energy yield, torrefied liquid products, compositional analysis 


\section{Introduction}

Biomass is the widely available and the largest renewable resources for producing biofuels to address the diminishing fossil energy reserves and to mitigate the environmental issues from the petroleum-based fuels (Zhang et al., 2012). Lignocellulose biomass, especially energy crop, has attracted extensive attention for its affluent availability, high biomass yield potential, and non-food competition. It was reported by the United States Department of Energy (DOE) that around $1.2 \times 10^{9}$ dry Mg of lignocellulose biomass could be obtained annually with more than 50\% from energy crops for biofuels production (Perlack et al., 2005) through thermochemical and biochemical conversion routes. Among energy crops, sorghum is a unique plant feedstock in that all its aboveground growth components (stem sap sugar, biomass or grain) can be converted into biofuel. It was traditionally grown as a fodder and has been selected and bred syrup and food purposes. It is a C4 crop characterized by a high photosynthetic efficiency. Sorghum can be grown successfully between the latitudes of $45.0^{\circ} \mathrm{N}$ to $52.0^{\circ} \mathrm{S}$. It is an annual plant with short crop cycle (3-5 months) to maturity. In tropical and sub-tropical climates, it can be grown more than one crop a year. Furthermore, sorghum is tolerant to many stresses including drought, heat, and salinity (Almodares and Hadi, 2009; Prasad et al., 2008).

Forage varieties including those with photoperiod-sensitive types and high in biomass content are categorized into high biomass or energy sorghums. They are typically taller, leafier and later maturing than grain varieties. Energy sorghum yield varies from 15 to 25

$\mathrm{Mg} \mathrm{ha}^{-1}$, but yields as high as $40 \mathrm{Mg} \mathrm{ha}^{-1}$ has been reported (Packer and Rooney, 2014). Sweet sorghum provides another source of substantial biomass. Plant stalk is rich in 
fermentable sugars (70-80\% as sucrose and the remaining as glucose and fructose) for syrup or ethanol production (Rooney et al., 2007; Murray et al., 2008). The combined sugar content of the juice varies from 9 to $15 \%$, and sugar yields range from 3.6 to $15.5 \mathrm{Mg} \mathrm{ha}^{-1}$. The bagasse, the byproduct of stalk after juice extraction represents approximately twothird of the dry biomass, and has limited value due to low energy content, reported in $\mathrm{MJ} / \mathrm{kg}$. (Vermerris et al., 2008). Both sorghums can be widely planted on marginal land in the US and could be utilized for producing biofuels, bioenergy and biochemicals.

Torrefaction, low temperature $\left(200-300^{\circ} \mathrm{C}\right)$ pyrolysis process carried out under the anoxic condition produces torrefied solid biomass, condensable liquids and non-condensable gases. During torrefaction, the fibrous structure and tenacity of biomass are destroyed (Stelt et al., 2011); oxygen and water are removed through carboxylation and dehydration reactions; thus nearly doubled the energy density of the torrefied solid biomass, which could be further used as the feedstock for gasification and co-firing to produce heat and power.

For biofuels production from lignocellulosic biomass, the structural and compositional heterogeneity, low energy density and non-uniform physical characteristics impair the efficiency of economic logistics, grindability and energy yield of biofuels. Torrefaction, a promising thermal pretreatment has been widely reported for biofuel production to improve low-quality biomass into physically consistent feedstock with higher energy density and lower moisture. Phanphanich and Mani investigated the impact of grindability on torrefied woodchips and reported the improved fuel properties for co-firing applications. The higher heating values of torrefied pinewood chips increased up to $37.5 \%$ when torrefied from 250 to $300{ }^{\circ} \mathrm{C}$ with the energy yield of 71-90\% (Phanphanich and Mani, 2011). Zhang and 
Hilten studied the effects of torrefaction on bio-oil production with non-catalytic and catalytic fast pyrolysis respectively. They found that pyrolysis bio-oil quality, to some extent, was improved with elevated torrefaction temperature; however, the cross-reaction fragments between lignin and cellulose were proposed to impair the yield of aromatic hydrocarbons (Zhang et al., 2012; Hilten et al., 2013). Deng et al. evaluated the torrefaction pretreatment of agriculture wastes on co-gasification with coal (Deng et al., 2009) and indicated the integration of torrefaction and gasification significantly increased the energy efficiency. Couhert et a. reported the improvement on syngas quality with torrefied feedstock and reported that approximately the same quantities of $\mathrm{CO}_{2}, 7 \%$ more $\mathrm{H}_{2}$ and $20 \%$ more $\mathrm{CO}$ were obtained from torrefied beechwood after gasification for $2 \mathrm{~s}$ at $1400 \mathrm{C}$ (Couhert et al., 2009). Most current research concentrated on the characterization and the application of torrefied biomass. However, as far to our knowledge, the liquid products generated during torrefaction was not investigated in detail. The condensable liquid products from torrefaction are derived from volatile components in holocellulose and partial degradation of lignin and could be extracted into oil and aqueous fraction, and could be further upgraded into high-value platform chemicals or refined into drop-in fuels. However, limited knowledge is available in the literature on the composition of torrefied liquid products and their fractional yields to evaluate the technical feasibilities of producing co-products. The low energy density of raw sorghum (less than $16 \mathrm{MJ} \mathrm{kg}^{-1}$ ) can be improved by torrefaction for energy applications while generating valuable liquid coproduct. The main objectives of this study were to (i) investigate the impact of torrefaction temperature on the mass yield and improved energy density of sorghum biomass; (ii) 
analyze the chemical compositions of torrefaction products for its potential to produce value-added platform chemicals.

\section{Materials and Methods}

\subsection{Materials}

Energy sorghum and sweet sorghum bagasse were obtained from the ongoing field trials at the Fort Valley State University, Fort Valley, Georgia, USA. The experimental site was located at $32^{\circ} 30^{\prime} \mathrm{N}$ and $83^{\circ} 52^{\prime} \mathrm{W}$, with an elevation of $155 \mathrm{~m}$ above mean sea level. Average (40-yr) air temperature at the site ranges from $8^{\circ} \mathrm{C}$ in January to $27^{\circ} \mathrm{C}$ in July and total annual precipitation is $1215 \mathrm{~mm}$. A basal fertilization of $0-20-20 \mathrm{NPK}$ at the rate of 50 $\mathrm{kg} \mathrm{ha}^{-1}$ was applied. Sorghum varieties EJ7281 (sweet sorghum) and ES5200 (energy sorghum) (Ceres Inc., Thousand Oaks, California) were planted in late May at the rate of 123,500 and 197,600 seeds $\mathrm{ha}^{-1}$, fertilized with $\mathrm{N}$ at the rate of $90 \mathrm{~kg} \mathrm{ha}^{-1}$. Sweet sorghum plots were harvested at dough stage and energy sorghum in mid-October. Sweet sorghum stalk was squeezed for sugar. Both energy sorghum and bagasse were the first field dried, and subsequently, open air dried in the shade.

Energy sorghum and sweet sorghum bagasse were chopped using a forage chopper with the chop length ranging from $10 \mathrm{~mm}$ to $240 \mathrm{~mm}$ in length and pre-dried before torrefaction. Two annual samples (2012 and 2013) of above two sorghum biomasses were employed for the compositional analysis with three replications. The average moistures of energy sorghum and sweet sorghum bagasse were 9.29 wt. $\%$ and 7.83 wt. $\%$ respectively. The 
ultimate analysis, proximate analysis, higher heating values (HHVs) and holocellulose content were measured and listed in Table 1 and Fig.3 (raw sorghums).

Solvents of dichloromethane and sulfuric acid used in this study were obtained from Sigma-Aldrich with chemical pure. Calcium carbonate used for wet chemical analysis was also purchased from Sigma-Aldrich.

\subsection{Torrefaction experiment}

Energy sorghum and sweet sorghum bagasse were torrefied in a steel batch torrefaction reactor $(30 \mathrm{~cm} \times 30 \mathrm{~cm} \times 15 \mathrm{~cm})$, which was placed inside a heated electric furnace. For each run, approximately $600 \mathrm{~g}$ of sample was added into the reactor. The reactor was sealed with steel gasket to avoid gas product leaking during torrefaction. The air inside the reactor was purged and displaced with nitrogen before heating and nitrogen were continuously passed through the reactor with the influx rate of $2 \mathrm{lpm}$ (liter per minute) to avoid ignition and oxidation throughout the torrefaction process. Torrefaction experiment was conducted at three temperatures $\left(250,275\right.$ and $\left.300^{\circ} \mathrm{C}\right)$ for $30 \mathrm{~min}$ as per the procedure described elsewhere (Phanphanich and Mani, 2011). The reaction temperature was monitored and controlled with a thermocouple, which was inserted through a $15 \mathrm{~cm}$ fillister into the center

of the reactor. The temperature was recorded with an average heating rate of $1.15^{\circ} \mathrm{C} \mathrm{min}{ }^{-1}$ until the desired temperature was reached. The evaporated gas product from sorghum feedstock was condensed with a series of four metal condensers, cooled with ice-bath. The condensable gas was collected in the form of liquid product at the bottom of four condensers. Non-condensable gas was exhausted into the atmosphere through a water bath. After the torrefaction reaction, the reactor was cooled with fans until reaching the room 
temperature. Nitrogen influx was stopped until the reactor temperature dropped below $50{ }^{\circ} \mathrm{C}$. The torrefied sorghum and the condensable liquid sample were collected and weighed respectively. The torrefied sorghum samples were sealed and stored at room temperature, while the liquid samples were collected and stored in the refrigerator. Each torrefaction condition was repeated three times.

\subsection{Separation and extraction}

For each torrefaction condition, $50 \mathrm{ml}$ dichloromethane solvent was added into liquid samples in the four condensers and successively collected into a separatory funnel. The oil fraction in the mixture was extracted and decanted off from the aqueous phase using dichloromethane. If the aqueous fraction appeared dark brown, there was residual oil and scattered tar remaining. Additional $10 \mathrm{ml}$ dichloromethane was applied to extract the organic components until the aqueous phase appeared clear. Both oil fraction and aqueous fraction were weighed and stored in the refrigerator for compositional analysis.

\subsection{Analysis of torrefied products}

\subsubsection{Analysis of torrefied solids}

The torrefied sorghum samples were ground with ball mill into a fine powder and dried at $105^{\circ} \mathrm{C}$ in the convective oven overnight before analysis. The torrefied powder samples were analyzed for ultimate analysis and proximate analysis with three replications. The former measurement was determined using an elemental analyzer (LECO CHNS 932, LECO Corporation, St. Joseph, MI), based on the procedure of ASTM D3176-89, where oxygen content was obtained by difference (ASTM 2002a). The latter was conducted with a 
micro thermo-gravimetric analyzer (TGA701, LECO Corporation, St. Joseph, MI), based on the procedure of ASTM D 5142-04 for coke, where the contents of ash, volatiles, and fixed carbon were reported on a dry basis (ASTM 2002b).

The higher heating value (HHV) of torrefied sorghums were also determined using an adiabatic oxygen bomb calorimeter (IKAC 2000, IKA Works, Inc., NC). The compositions of hemicellulose, cellulose and lignin were determined with wet chemical analysis according to the National Renewable Energy Laboratory (NREL) standard protocol (Selig et al., 2008).

The lignin components of both raw sorghums and torrefied sorghums were analyzed with pyro-GC/MS. Around $2.0 \mathrm{mg}$ of each sample was single-shot pyrolyzed at $500{ }^{\circ} \mathrm{C}$ with Frontier lab pyrolyzer (PY-2020 iD) with three replications. The volatile compounds were separated with HP-5ms Capillary Column (30m x 0.25um x 0.25mm) (Agilent Technologies Inc., CA) in a $6890 \mathrm{~N}$ GC system. The oven temperature program was initially set at $50{ }^{\circ} \mathrm{C}$ for $2 \mathrm{~min}$; then ramped to $280^{\circ} \mathrm{C}$ with the heating rate of $5{ }^{\circ} \mathrm{C} \mathrm{min}^{-1}$ and constantly kept for 53 min. Helium was employed as a carrier gas with the flow rate of 1 $\mathrm{ml} \mathrm{min}{ }^{-1}$, and the split ratio was set at 50:1. The lignin components were identified by matching fragmentation patterns with the NIST (National Institute of Standards and Technology) 11 mass spectral library.

\subsubsection{Analysis of torrefied liquids}

The components of aqueous fraction and oil fraction from liquid product were respectively analyzed by GC-MS using HP-5ms Capillary Column (30m x $0.25 \mathrm{um}$ x $0.25 \mathrm{~mm}$ ). The oven temperature program was initially set to $40{ }^{\circ} \mathrm{C}$ for $4 \mathrm{~min}$; then increased to $275{ }^{\circ} \mathrm{C}$ 
with the heating rate of $5^{\circ} \mathrm{C} \min ^{-1}$ and constantly held for $5 \mathrm{~min}$. The Mass Spec interface was set at $280^{\circ} \mathrm{C}$. The inlet temperature was $260^{\circ} \mathrm{C}$. Helium was used as carrier gas with the flow rate of $0.8 \mathrm{~mL} \mathrm{~min} \mathrm{~m}^{-1}$ and the split ratio of 50:1. The liquid sample volume injected was one $\mu \mathrm{l}$. The solvent delay was set up for $3 \mathrm{~min}$ for dichloromethane. The compositions of the samples were identified by matching fragmentation patterns with NIST mass spectral library.

The major compounds in aqueous fraction were determined by HPLC using Coragel 94 column. The oven temperature was kept constant at $60^{\circ} \mathrm{C}$, and $4 \mathrm{mN}$ sulfuric acid was used for mobile phase. The flow rate was constant at $0.6 \mathrm{ml} \mathrm{min}^{-1}$. The sample volume injected was $5 \mu \mathrm{l}$. The concentrations of water soluble products were determined and reported.

\subsection{Calculation of torrefied product yields}

The torrefied products included solid torrefied sorghum, non-condensable gas, and condensable liquid, which further separated into aqueous and oil fraction. The yields of above products were calculated as follows (Zheng et al., 2012):

Yield of torrefied sorghum $=\frac{\text { mass of torrefied sorghum }}{\text { mass of sorghum feedstock }} \times 100 \%$

Yield of condensable liquid $=\frac{\text { mass of liquid product }}{\text { mass of sorghum feedstock }} \times 100 \%$

Yield of gas fraction $=1-\frac{\text { mass of torrefied sorghum }}{\text { mass of sorghum feedstock }}-\frac{\text { mass of liquid product }}{\text { mass of sorghum feedstock }} \times 100 \%$

Yield of aqueous fraction $=\frac{\text { mass of aqueous product }}{\text { mass of sorghum feedstock }} \times 100 \%$ 
Yield of oil fraction $=\frac{\text { mass of liquid product }- \text { mass of aqueous product }}{\text { mass of sorghum feedstock }} \times 100 \%$

\subsection{Statistical analysis}

The HHVs of torrefied sorghums were compared among three torrefaction temperatures $\left(250,275\right.$ and $\left.300{ }^{\circ} \mathrm{C}\right)$ with one-way ANOVA and Turkey multiple comparison tests. SAS program (Version 9.4) was employed to implement above statistical analysis with the significant difference level at $P<0.05$.

\section{Results and Discussions}

\subsection{Characterization of sorghum biomass}

Energy sorghum and sweet sorghum bagasse were mainly constituted with moisture, ash, holocellulose and lignin. The components of energy sorghum were $7.83 \%$ of moisture, $3.47 \%$ of ash, $21.44 \%$ of hemicellulose, $33.24 \%$ of cellulose and $19.94 \%$ of lignin. The compositions of sweet sorghum bagasse were $9.29 \%$ of moisture content, $3.28 \%$ of ash, $18.50 \%$ of hemicelluloe, $33.15 \%$ of cellulose and they were similar to those of energy sorghum. The dominant structural unit of p-hydroxyl phenol (H lignin) was present in both sorghums. The HHVs of energy sorghum and sweet sorghum bagasse were $17.33 \mathrm{MJ} \mathrm{kg}{ }^{-1}$ and 16.45 $\mathrm{MJ} \mathrm{kg}^{-1}$ respectively, which were comparable to rice straw (Deng et al., 2009) and birch (Pach et al., 2002). The O/C and $\mathrm{H} / \mathrm{C}$ ratios were 0.87 and 1.54 for energy sorghum; and 0.99 and 1.61 for sweet sorghum bagasse respectively. The compositional characteristics of both sorghum samples were summaried in Table 1. 


\subsection{Yields of torrefied products}

During torrefaction, free water, and physically bound water were successively released from sorghum biomass when the temperature reached from 100 to $200{ }^{\circ} \mathrm{C}$ (Stelt et al., 2011). Most hemicellulose and a small amount of lignin started to decompose mainly through decarboxylation and dehydration reactions after $200^{\circ} \mathrm{C}$. Cellulose and most lignin were more tolerant and decomposed fractionally at higher torrefaction temperature; most unbinding cellulose and lignin were more brittle to breakdown and aggregate into acid insoluble components. The resultant solid product appeared darker, and the yields decreased with increased torrefaction temperature due to continuous decomposition of remaining solids. The solid yields ranged between $53.1-69.8 \%$ for torrefied energy sorghum and 41.3 - $64.7 \%$ for torrefied sweet sorghum bagasse respectively (Fig.1). The yields of condensable liquid and non-condensable gas, derived from sorghum volatiles, increased with temperature. There was no significant difference in non-condensable gas

yields between two sorghums at each temperature, which mainly constituted with $\mathrm{CO}_{2}$ and $\mathrm{CO}$ generated from the decarboxylation of hemicellulose and part of cellulose. However, the more condensable liquid product was produced from sweet sorghum bagasse than that of energy sorghum. When the temperature increased from 250 to $300{ }^{\circ} \mathrm{C}$, the yield of aqueous fraction from energy sorghum gradually increased from $9.44 \%$ to $15.29 \%$; whereas, the liquid yield from sweet sorghum bagasse was increased from $15.27 \%$ to $23.33 \%$ due to higher decomposition rate (Fig.1). The compositional analysis of torrefied sorghums revealed that more than $90 \%$ of hemicellulose and $44 \%$ of cellulose in the sweet sorghum 
bagasse were decomposed as compared to $70 \%$ of hemicellulose and $25 \%$ of cellulose for energy sorghum at $250^{\circ} \mathrm{C}$.

\subsection{Characterization of torrefied solids}

The compositions of torrefied samples were reported in Table 1. The oxygen present in the biomass was reduced with temperature through decarboxylation and dehydration reactions from hemicellulose and partially depolymerized cellulose. It was reduced by $10.95 \%$ for energy sorghum and $18.83 \%$ for sweet sorghum bagasse respectively at $300{ }^{\circ} \mathrm{C}$, which caused the decreased $\mathrm{O} / \mathrm{C}$ ratios. $\mathrm{H} / \mathrm{C}$ ratios of two torrefied sorghums also reduced due to the reduction of hydroxyl substitutes. Van Krevelen diagram, widely suited to analyze compositional characterizations of various fuels by differentiating zones, was employed to compare the compositional difference of torrefied sorghums between coals and torrefied pine chips. It was clearly indicated that the elemental distribution of torrefied sorghums was approaching to lignite coal with temperature (Fig.2) The torrefied pine chips displayed desirable $\mathrm{H} / \mathrm{C}$ and $\mathrm{O} / \mathrm{C}$ ratios than that of torrefied herbaceous biomass. This was mainly due to the difference in initial holocellulose and lignin contents of raw biomass. The similar slope of $\mathrm{H} / \mathrm{C}$ to $\mathrm{O} / \mathrm{C}$ ratios between torrefied pine chips and torrefied sorghums indicated the impact of torrefaction process were close on fuel properties improvement, which benefited more from torrefaction conditions rather than feedstock types

The energy yields of torrefied sorghums also shared the same trend of 85,73 and $70 \%$ of torrefied energy sorghum at 250,275 and $300{ }^{\circ} \mathrm{C}$ respectively. Considering the torrefied energy sorghum yield, energy densities increased to 21,37 and $36 \%$ at above three torrefaction temperatures respectively. After torrefaction, about 70 to $79 \%$ of original 
energy was stored in the torrefied sweet sorghum bagasse, but the energy density increased up to $64 \%$. This energy reward was less desirable than torrefied wood biomass (Bergman et al., 2005), which was around $90 \%$ of the initial energy content in the torrefied solid product. The structural carbohydrates in woody biomass were more tolerance to thermal decomposition than that of herbaceous biomass during torrefaction conditions. The difference in feedstock decomposition rate was confirmed by Prins's report that for torrefied willow, the formation of acetic acid occurred at higher temperature $\left(300^{\circ} \mathrm{C}\right)$, thus resulted in energy density change with torrefaction temperature (Prins et al., 2006). In this study, with herbaceous sorghum, most of the acetic acids was found to be formed before $250^{\circ} \mathrm{C}$ from hemicellulose thermal decomposition.

The holocellulose and lignin components of torrefied sorghums were shown in Fig. 3. The residual hemicellulose contents of torrefied energy sorghum were 9.6, 3.2 and $2.6 \%$ at $250{ }^{\circ} \mathrm{C}, 275^{\circ} \mathrm{C}$ and $300{ }^{\circ} \mathrm{C}$ respectively. For sweet sorghum bagasse, more hemicellulose was degraded at the same condition. Cellulose from sweet sorghum bagasse were also more susceptible to thermal degradation. The original cellulose content of $5.37 \%$ for sweet sorghum bagasse and $21.5 \%$ for energy sorghum was intact at $300{ }^{\circ} \mathrm{C}$. It was also indicated that the aggregation of breakdown cellulose and lignin was the dominant component, ranging from 60 to $80 \%$ in torrefied sorghums after $275^{\circ} \mathrm{C}$, in which, around $99 \%$ was acid insoluble fraction.

During pyrolysis, the lignin units, p-hydroxyphenyl $(\mathrm{H})$, guaiacyl $(\mathrm{G})$, and syringyl $(\mathrm{S})$ phenylpropanoids were decomposed into p-coumaryl alcohol, coniferyl alcohol, and sinapyl alcohol respectively (Boerjan et al., 2003). During torrefaction, H lignin was 
dramatically degraded and became stable at $22-24 \%$ for both sorghums after $250^{\circ} \mathrm{C}$. The $\mathrm{S}$ and $\mathrm{G}$ lignin groups were degraded partially and retained to $33-35 \%$ and $41-45 \%$ respectively after $250^{\circ} \mathrm{C}$ (Fig.3). Although the distribution of lignin units was different in the raw biomass, their contents became uniform after torrefaction.

\subsection{Characterization of liquid products}

The liquid products consisted of oil fraction and aqueous fraction after extraction with dichloromethane. The oil fraction contained the light oil components and tars containing heavy sticky liquids and composed of large molecular compounds. These large molecular compounds were commonly formed during torrefaction and pyrolysis, and soluble to most organic solvents. The components of liquid products were determined by GC/MS. There were hundreds of compounds existed in either aqueous or oil fraction, and it was hard to identify all of them. The major compounds were analyzed and listed in Table 2. HPLC was also implemented for quantitative analysis of main compounds in aqueous fraction and their

yields were indicated in Fig.4. The structural heterogeneity and compositional differences of raw samples led to distinct decomposition intermediates and cross reactions, which influenced the final components distribution in torrefied liquids between energy sorghum and sweet sorghum bagasse.

\subsubsection{Compositions of oil fraction}

The oil fraction was mainly composed of organic acids, phenolic type chemicals, furan derivatives, and ketones. There was no significant difference in the distribution of the large organic components identified between sorghum liquid products from $250^{\circ} \mathrm{C}$ to $275^{\circ} \mathrm{C}$. 
However, remarkable cross reactions between holocellulose and lignin decompositions occurred from $275^{\circ} \mathrm{C}$ to $300{ }^{\circ} \mathrm{C}$, typically influenced by the distributions of phenol derivatives and ketones. The former was mainly converted from hemicellulose and lignin and could be further upgraded for biofuels. Multiple phenol derivatives were formed after torrefaction. The simple structural phenol (phenol and its methyl-/ethyl- derivate) was formed from hemicellulose decomposition due to the simple unit structure of hemicellulose; while the phenol derivatives with methoxy substitutes was considered to be generated from lignin decomposition (Boerjan et al., 2003). Despite partial decomposition, it was also found that the lignin contributed more phenol derivatives than that of hemicellulose. The major products from hemicellulose were acetic acids and $\mathrm{CO}_{2}$, which intended to reduce oxygen content rather than to produce oil compounds during torrefaction.

Furans derivatives identified with abundance as well, especially from sweet sorghum bagasse torrefaction. Furfural was the dominant compound of furans derivative, which was formed from both hemicellulose and cellulose decomposition. Under hemicellulose decomposition route, furfural was converted from xylan after depolymerization, rearrangement and dehydration (Patwardhan et al., 2011); from cellulose decomposition, anhydrosugars, primarily levoglucosan, were first formed, then converted into furfural and formaldehyde through 5-hydroxymethylfurfural (5-HMF) dehydroxylation (Shen and Gu, 2009). More furfural was observed from sweet sorghum bagasse due to more holocellulose decomposition than that of energy sorghum. Another critical component in oil fraction was ketones. Cyclic ketones were reported to be derived from secondary cellulose decompositions in oil fraction (Wang et al., 2011); however, in our study, only linear 
ketones were identified, which were derived from holocellulose decomposition through ring scission, decarboxylation, dehydration and rearrangement (Shen and $\mathrm{Gu}, 2009$ ). The different ketones composition in this study was mainly led from different feedstocks and secondary cross reactions. Although acetic acid was the dominant compound in oil fraction from both sorghum samples, it appears that the acetate acid was the residue left after dichloromethane extraction. Additionally, depolymerization and defragment reactions also occurred on cellulose, which formed glucose derivatives (1,6;2,3-dianhydro-4-O-acetylbeta-d-gulopyranose) and other secondary intermediates.

\subsubsection{Compositions of aqueous fraction}

Water was the dominant component in aqueous fraction. Most condensed water was derived from free water and physically bound water in sorghums; while a small portion was obtained from the dehydration reaction. Acetic acid was the second dominant component in aqueous fraction. Its amount and yields from both sorghums were increased with temperature (Table 2 and Fig. 5). The maximum yield of acetic acid from energy sorghum and sweet sorghum bagasse in aqueous fraction were $92.61 \mathrm{~g} \mathrm{~L}^{-1}$ and $101.90 \mathrm{~g} \mathrm{~L}^{-1}$ respectively at $300^{\circ} \mathrm{C}$ for $30 \mathrm{~min}$. There were two main pathways to form acetic acid during torrefaction. The main route was through the cleavage of acetyl group on hemicellulose unit with the release of $\mathrm{CO}_{2}$ (Shen et al., 2010); the other route was from the cellulose decomposition intermediate of 5-HMF (Wang et al., 2011). Sweet sorghum bagasse produced large fraction of acetic acid as it was more susceptible to faster decomposition than that of energy sorghum during torrefaction. 
Other than organic acids, alcohols and ketones were the major components in the energy sorghum aqueous fraction, while furan type chemicals were the major aqueous components from sweet sorghum torrefaction (Table 2). Although the distribution of compounds in aqueous fraction from each sorghum type was unclear, the resultant products were derived from various decomposition routes, plus cross reactions between individual compound intermediates. It was proposed that furan intermediates be formed firstly from holocellulose of both sorghums. In energy sorghum, these furan intermediates were more apt to defragment further into $\mathrm{C} 4$ alcohols, such as butanol, through the precursor of furfuryl alcohols (Sitthisa and Resasco, 2011). The formed alcohols had relevant strong polarity and were easy to dissolve with water. For sweet sorghum bagasse, as the hemicellulose decomposition was more accessible, the furans intermediates were formed earlier and more apt to convert into relevant stable chemicals in the form of furfural and furan carboxaldehydes. Additionally, aldehydes type chemicals were also identified in the aqueous fraction of sweet sorghum bagasse through the ring scission and decarboxylation reactions of levoglucosan. Among those identified aldehydes, hydroxy acetaldehyde was widely reported as a cellulose thermal decomposition product (Lin et al., 2009; Shen et al., 2009)

Most major compounds in aqueous fraction increased with temperature. Hydroxyacetone and methanol had higher yields from energy sorghum reached to $13.73 \mathrm{~g} \mathrm{~L}^{-1}$ at $300^{\circ} \mathrm{C}$ and $12.43 \mathrm{~g} \mathrm{~L}^{-1}$ at $275^{\circ} \mathrm{C}$. For both sorghums, the methanol yield reached a maximum at $275^{\circ} \mathrm{C}$ and then decreased at $300^{\circ} \mathrm{C}$; the decomposition route of methanol is still unclear. 5-HMF was only formed from sweet sorghum bagasse with a concentration of $2.8-3.2 \mathrm{~g} \mathrm{~L}^{-1}$ at each 
torrefaction temperature, through direct ring-opening or rearrangement reactions of glucose (Stefanidis et al., 2014). Furfural had a higher concentration from sweet sorghum bagasse and has reached to a maximum of $3.79 \mathrm{~g} \mathrm{~L}^{-1}$ at $300^{\circ} \mathrm{C}$. The major compounds in torrefaction aqueous fraction were quite similar to that of Stelt's study (Stelt et al., 2011) from pinewood. However, formic acid and lactic acid were not detected in this study, probably because of the competitive formation of acetic acid from hemicellulose (Patwardhan et al., 2011).

\section{Conclusions}

Torrefaction of sorghums biomass was pretreated to improve fuel properties such as energy density, proximate and elemental compositions, approaching to lignite coal for efficient cofiring and downstream conversion to produce biofuels. Approximately, $80 \%$ of energy stored in raw biomass was recovered after torrefaction. In addition, torrefaction generated a valuable liquid co-product containing mixture of chemical compounds that could be upgraded into platform chemicals. The aqueous fraction of a liquid product was rich in carboxylic acids, valuable precursors of liner ketones and alcohols; while the oil fraction was rich in phenol derivatives and other distinct decomposition intermediates and cross products.

\section{Acknowledgement}

The project was financially supported by the USDA-NIFA sustainable bioenergy research grant number GEOX-2010-03868 via Fort Valley State University. 


\section{References}

1. ASTM, 2002a. ASTM- D3176-89 - Standard practice for ultimate analysis of coal and coke. Annual Book of ASTM Standards, Section 5, vol. 05.06, American Society for Testing and Materials, West Conshohocken, PA (2002)

2. ASTM, 2002b. ASTM- D5142-04 Standard test methods for proximate analysis of the analysis sample of coal and coke by instrumental procedures. Annual Book of ASTM Standards, Section 5, vol. 05.06, American Society for Testing and Materials, West Conshohocken, PA (2002)

3. Almodares, A. and Hadi, M.R., 2009. Production of bioethanol from sweet sorghum: A review. Afr. J. Agric. Res. 4,772-780.

4. Bergman, P.C.A., Boersma, A.R., Zwart, R.W.R., Kiel, J.H.A., 2005. Torrefaction for biomass co-firing in existing coal-fired power stations "biocoal". Report ECN-C-05-013. Petten, The Netherlands: ECN

5. Boerjan, W., Ralph, J., Baucher, M., 2003. Lignin biosynthesis. Annu. Rev. Plant. Biol., 54, 519-549

6. Couhert, C., Salvador, S., Commandre' J- M., 2009. The impact of torrefaction on syngas production from wood. Fuel. 88, 2286-2290.

7. Deng, J., Wang, G.J., Kuang, J.H., Zhang, Y.L., Luo Y.H., 2009. Pretreatment of agricultural residues for co-gasification via torrefaction. J. Anal. Appl. Pyrolysis. 86, 331-337.

8. Horne, P. A., Williams, P. T, 1996. The reaction of oxygenated biomass pyrolysis model compounds over a ZSM-5 catalyst. Renew. Energy. 7, 131-144.

9. Lin, Y.C., Cho, J., Tompsett, G.A., Westmoreland P.R., Huber G.W., 2009. Kinetics and mechanism of cellulose pyrolysis, J. Phy. Chem. C. 113, 20097-20107.

10. Murray, S.C., Rooney, W.L., Hamblin, M.T., Mitchell, S.E., Kresovich, S., 2009. Sweet sorghum genetic diversity and association mapping for brix and height. Plant Genome. 2, 4862.

11. Pach, M., Zanzi, R., Bjornbom, E., 2002. Torrefied biomass a substitute for wood and char coal. In: 6th Asia-pacific international symposium on combustion and energy utilization.

12. Packer, D. J., Rooney, W.L., 2014. High-parent heterosis for biomass yield in photoperiodsensitive sorghum hybrids, Field Crops Res. 167, 153-158.

13. Patwardhan, P. R., Brown, R. C., Shanks, B. H, 2011. Product distribution from the fast pyrolysis of hemicellulose ChemSusChem. 4, 636-643.

14. Perlack, R.D., L.L. Wright, A.F. Turhollow, et al. Biomass as feedstock for a bioenergy and bioproduct industry: the technical feasibility of a billion ton annual supply. Reported prepared for DOE under contract DE-AC05-000R22725. 59. P. 2005

15. Phanphanich, M., and Mani, S., 2011. Impact of torrefaction on the grindability and fuel characteristics of forest biomass. Bioresour. Technol. 102, 1246-1253.

16. Prasad, P.V.V., Pisipati, S.R., Mutava, R.N., Tuinstra, M.R., 2008. Sensitivity of grain sorghum to high temperature stress during reproductive development. Crop Sci. 48, 19111917.

17. Prins, M.J., Ptasinski, K.J., Janssen, F.J.J.G., 2006. More efficient biomass gasification via torrefaction. Energy. 31, 3458-3470.

18. Roger N. Hilten, Richard A. Speir, James R. Kastner, Sudhagar Mani, and K. C. Das, 2013. Eff ect of Torrefaction on Bio-oil Upgrading over HZSM-5. Part 1: Product Yield, Product 
Quality, and Catalyst Eff ectiveness for Benzene, Toluene, Ethylbenzene, and Xylene Production. Energy Fuels. 27, 830-843

19. Rooney, W.L., Blumenthal, J., Bean, B., Mullet, J.E., 2007. Designing sorghum as a dedicated bioenergy feedstock. Biofuel Bioprod. Bior. 1920, 147-157.

20. Selig, M., Weiss, N., Ji, Y., 2008. In: Laboratory Analytical Procedure No. TP-510-42629. National Renewable Energy Laboratory, Golden, CO.

21. Sitthisa, S., Resasco, D. E, 2011. Hydrodeoxygenation of Furfural Over Supported Metal Catalysts: A Comparative Study of Cu, Pd and Ni. Catal. Lett. 141, 784-791

22. Shen, D., Gu, S., 2009. The mechanism for thermal decomposition of cellulose and it main products. Bioresour. Technol. 100, 6496-6504.

23. Shen, D.K., Gu, S., Bridgwater, A.V., 2010. Study on the pyrolytic behavior of xylan based hemicellulose using TG-FTIR and Py-GC-FTIR, J. Anal. Appl. Pyrol. 87, 199-206.

24. Stefanidis, S. D., Kalogiannis, K. G., Iliopoulou, E. F., Michailof, C. M., Pilavachi, P. A., Lappas, A. A., 2014. A study of lignocellulosic biomass pyrolysis via the pyrolysis of cellulose, hemicellulose and lignin. J. Anal. Appl. Pyrol. 105,143-150.

25. US Department of Agriculture (USDA), Natural Resources Conservation Service (NCRS). Custom Soil Resource Report. Accessed on 3/ 2/2015.

26. van der Stelt, M. J. C., Gerhauser, H., Kiel, J. H. A., Ptasinski, K. J., 2011. Biomass upgrading by torrefaction for the production of biofuels: A review. Biomass Bioenerg. 35, 3748-3762.

27. Vermerris, W., Rainbolt, C., Wright, D., Newman, Y., 2008. Production of biofuel crops in Florida: Sweet sorghum. University of Florida IFAS extension publication \#SS AGR 293, pp. 1-7.

28. Wang, S., Guo, X., Liang, T., Zhou, Y., Luo, Z., 2011. Mechanism research on cellulose pyrolysis by Py-GC/MS and subsequent density functional theory studies. Bioresour. Technol. 104, 722-728.

29. Zheng, A., Zhao, Z., Chang, S., Huang, Z., He, F., L, H., 2012. Effect of Torrefaction Temperature on Product Distribution from Two-Staged Pyrolysis of Biomass. Energy. Fuel. 26, 2968-2974. 

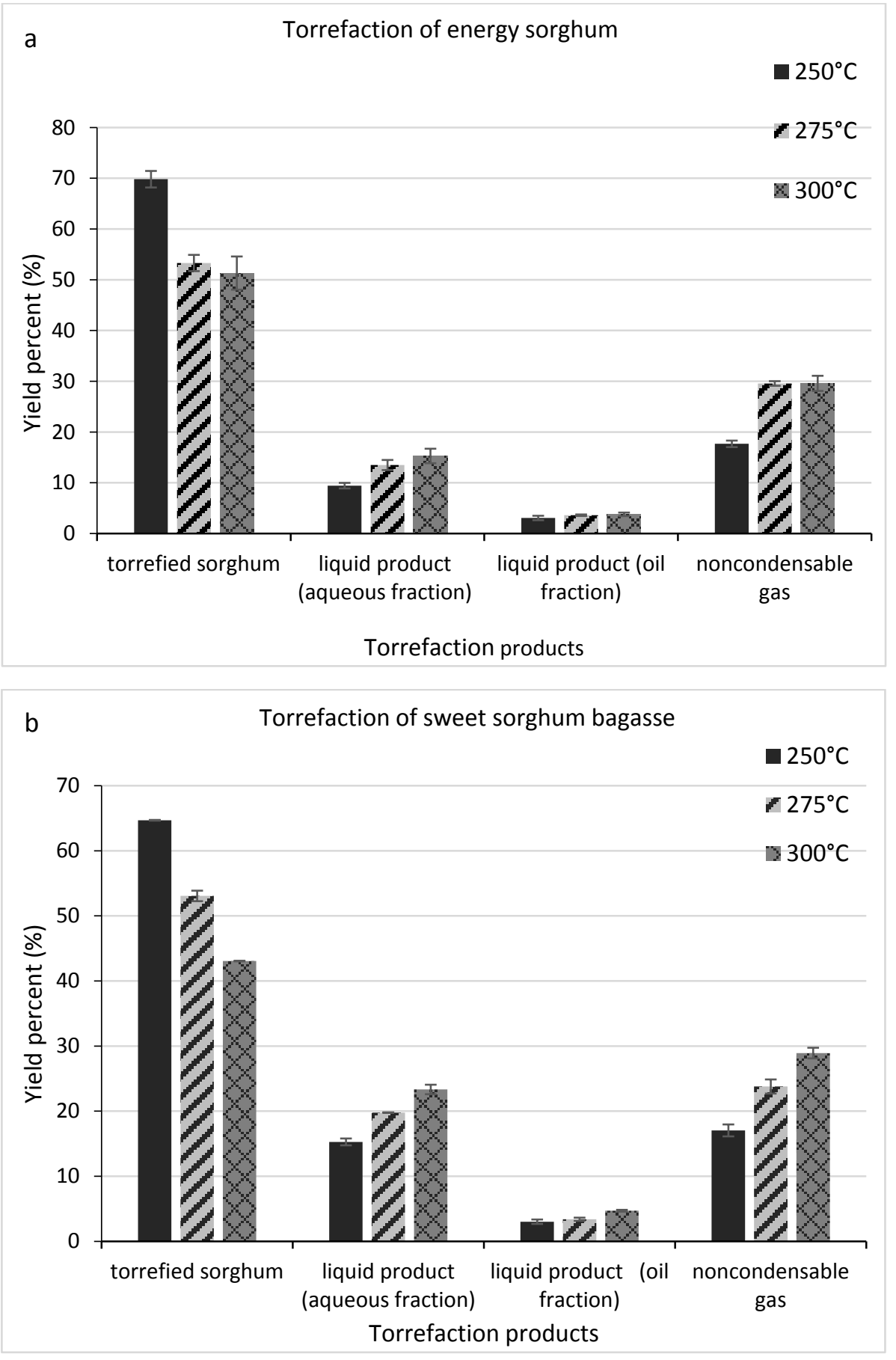

Fig.1 Torrefaction yields from sorghum biomass. The reaction time was $30 \mathrm{~min}$ for both sorghums 


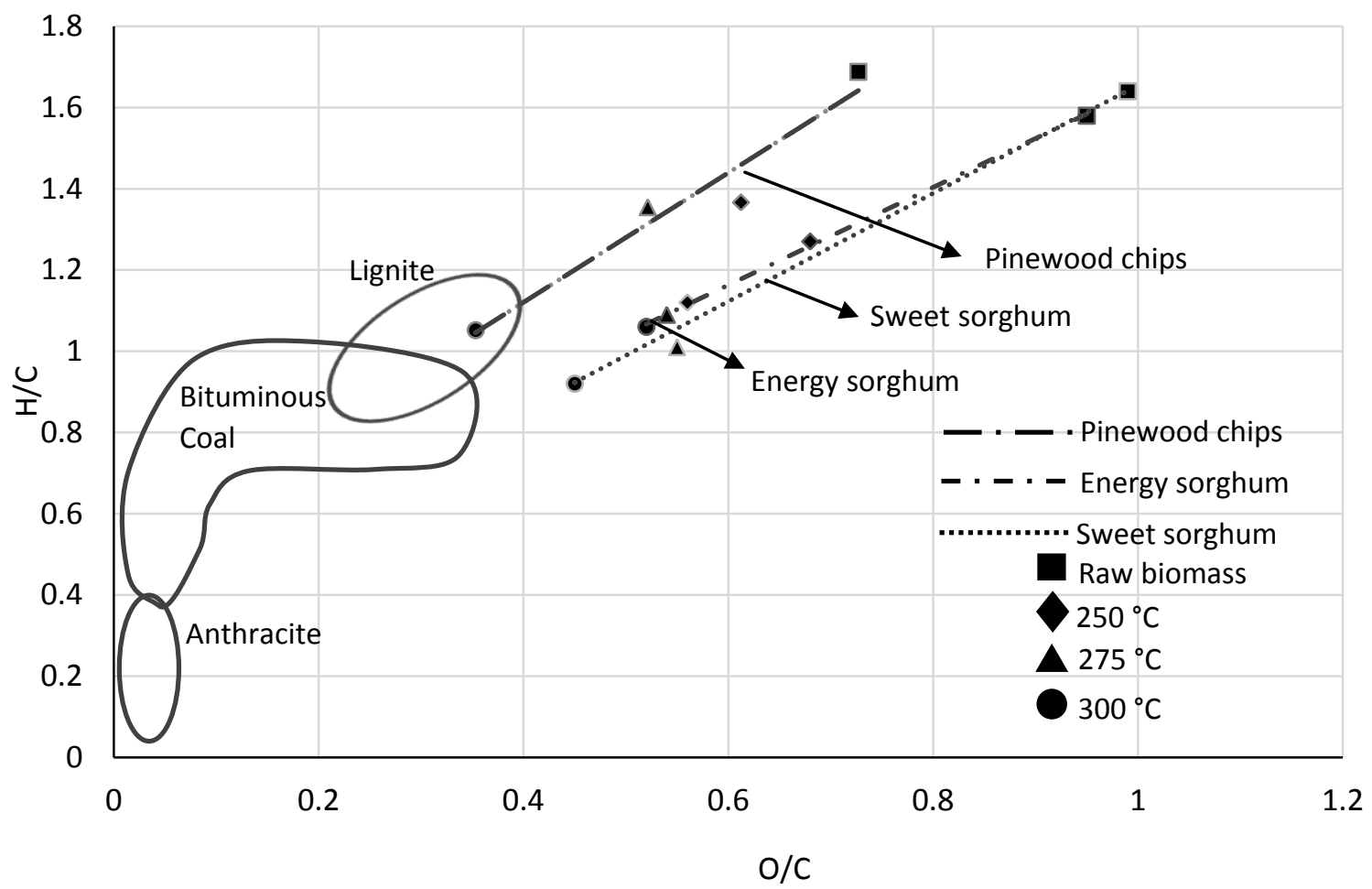

Fig.2 Van Krevelen Diagram for chemical composition of sorghums and wood biomass at various torrefaction temperature. (Data extracted from Phanphanich and Mani, 2011) 


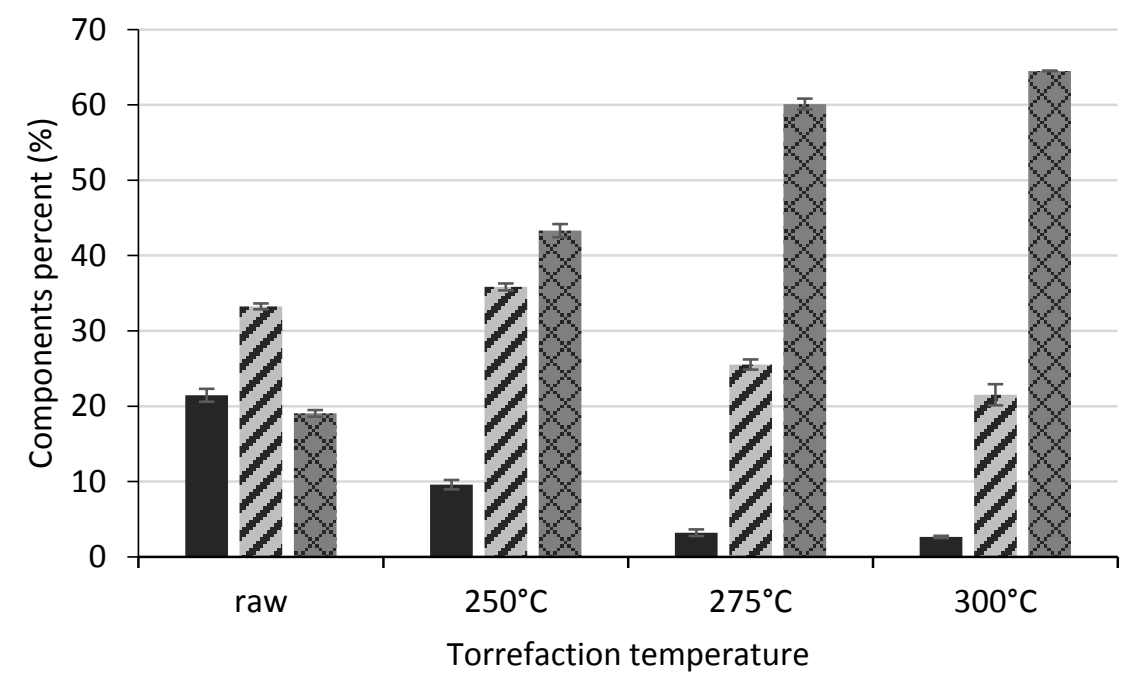

- hemicellulose cellulose $\quad$ acid insoluble components

b Torrefied sweet sorghum bagasse components

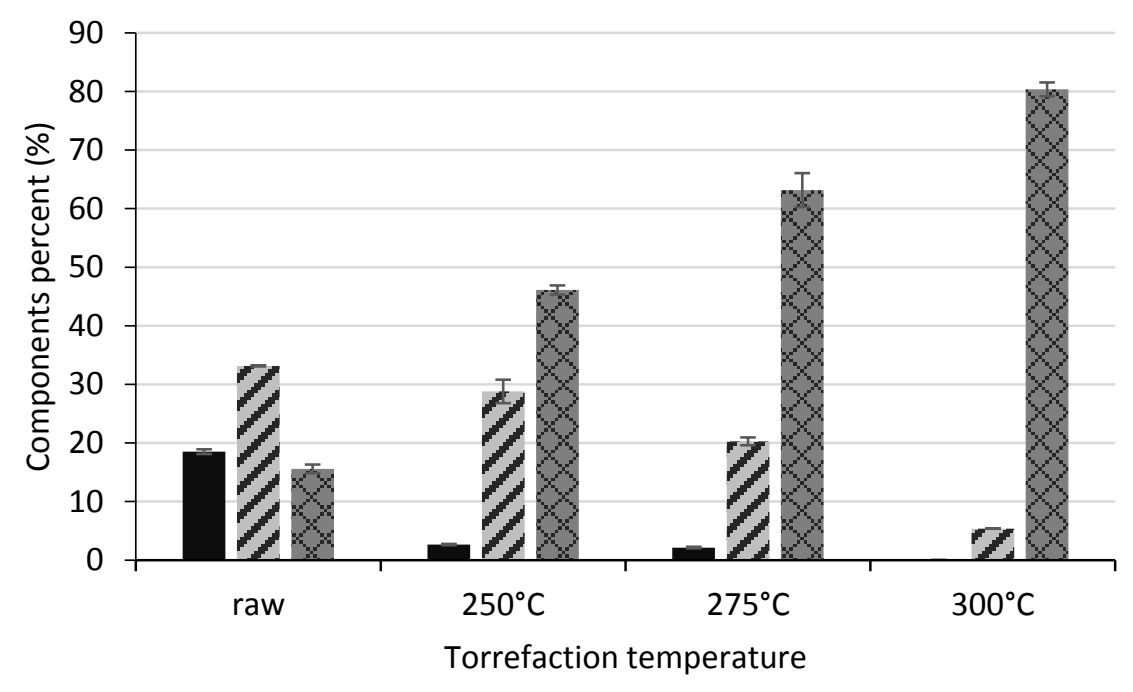

- hemicellulose cellulose $\quad$ acid insoluble components

Fig.3 Chemical composition analysis of torrefied sorghums 

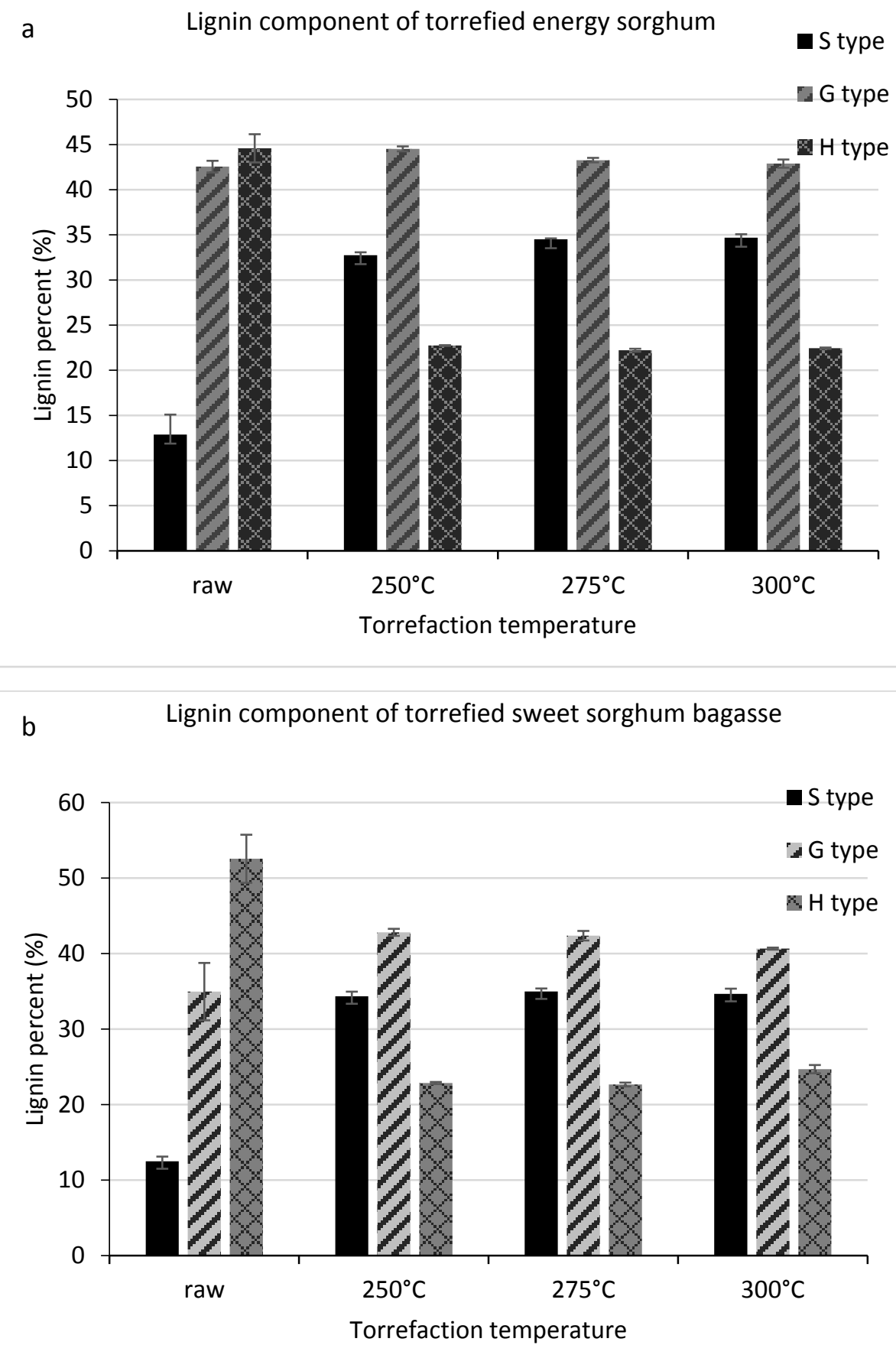

Fig.4 Lignin analysis of torrefied sorghums 


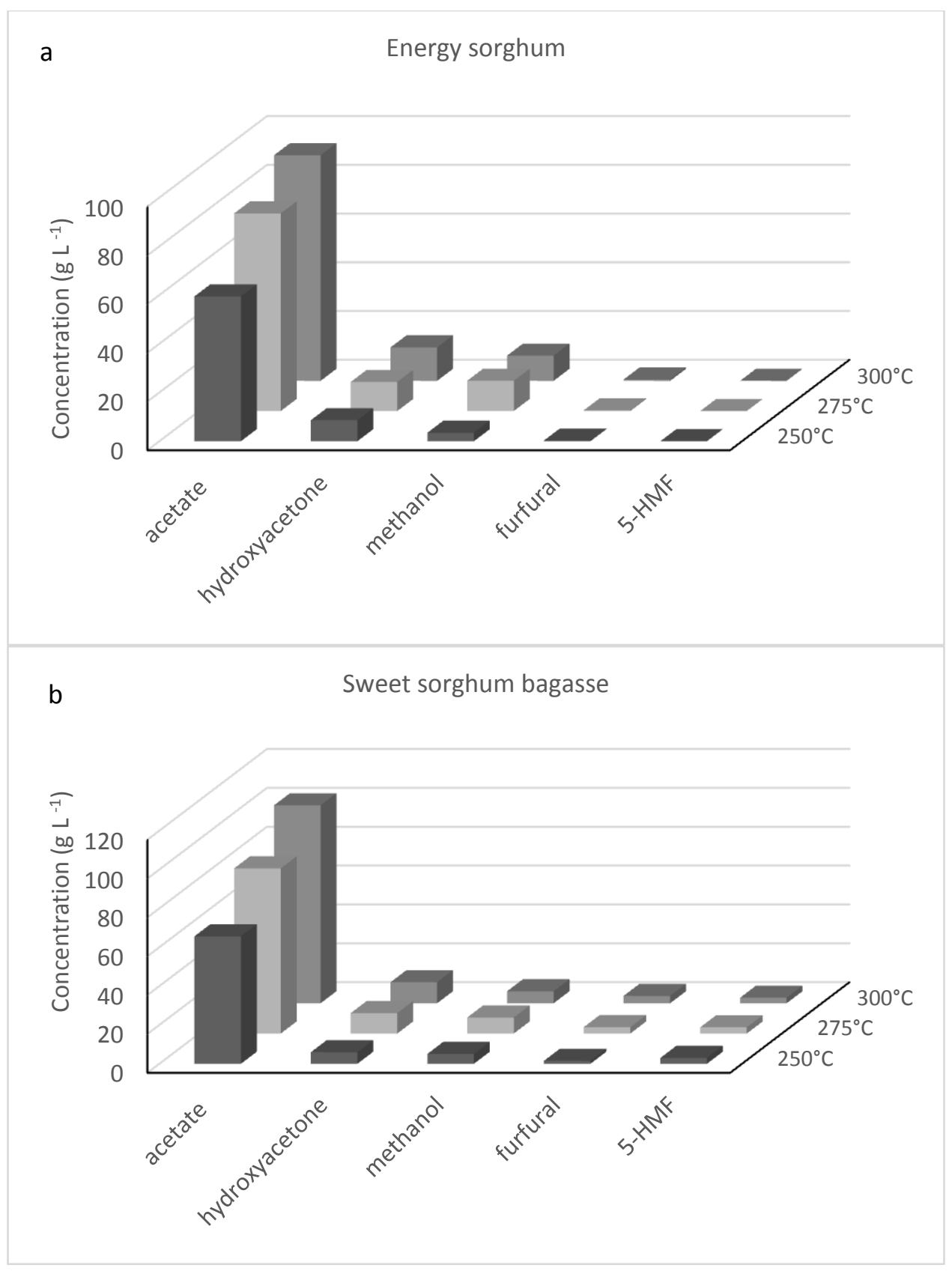

Fig.5 Yields of major compounds from aqueous product 
Table 1. Characterization of torrefied sorghums

\begin{tabular}{|c|c|c|c|c|c|c|c|c|c|c|}
\hline $\begin{array}{l}\text { Torrefied } \\
\text { Sorghum }\end{array}$ & Temperature & $\begin{array}{l}\text { Moisture } \\
\text { (\%) }\end{array}$ & $\begin{array}{c}\text { Fixed } \\
\text { Carbon } \\
(\%)\end{array}$ & $\begin{array}{l}\text { Volatiles } \\
\text { Dry }(\%)\end{array}$ & $\begin{array}{l}\text { Ash } \\
\text { Dry } \\
(\%)\end{array}$ & $\begin{array}{c}\mathrm{C} \\
\text { (wt.\%) }\end{array}$ & $\begin{array}{c}\mathrm{H} \\
\text { (wt.\%) }\end{array}$ & $\underset{(\text { wt.\%) }}{\mathrm{N}}$ & $\begin{array}{c}\mathrm{O}^{*} \\
\text { (wt. \%) }\end{array}$ & $\begin{array}{l}\mathrm{HHV}^{* *} \\
\left(\mathrm{MJ} \mathrm{kg}_{1}\right)\end{array}$ \\
\hline \multirow{4}{*}{$\begin{array}{c}\text { Energy } \\
\text { sorghum }\end{array}$} & raw & $\begin{array}{c}7.83 \\
(0.24)\end{array}$ & $\begin{array}{l}17.01 \\
(0.63)\end{array}$ & $\begin{array}{l}79.39 \\
(1.90)\end{array}$ & $\begin{array}{c}3.47 \\
(1.13)\end{array}$ & $\begin{array}{l}43.11 \\
(2.15)\end{array}$ & $\begin{array}{c}5.52 \\
(0.11)\end{array}$ & $\begin{array}{c}1.45 \\
(0.03)\end{array}$ & $\begin{array}{l}49.93 \\
(2.23)\end{array}$ & $\begin{array}{c}17.33 \\
(0.42)^{\mathrm{a}}\end{array}$ \\
\hline & $250^{\circ} \mathrm{C}$ & $\begin{array}{l}2.05 \\
(0.19)\end{array}$ & $\begin{array}{l}23.83 \\
(0.70)\end{array}$ & $\begin{array}{l}70.93 \\
(1.31)\end{array}$ & $\begin{array}{c}4.75 \\
(0.63)\end{array}$ & $\begin{array}{l}48.87 \\
(0.16)\end{array}$ & $\begin{array}{c}5.16 \\
(0.02)\end{array}$ & $\begin{array}{c}1.56 \\
(0.03)\end{array}$ & $\begin{array}{l}44.42 \\
(0.12)\end{array}$ & $\begin{array}{l}21.01 \\
(0.41)^{\mathrm{b}}\end{array}$ \\
\hline & $275^{\circ}$ & $\begin{array}{c}1.82 \\
(0.52)\end{array}$ & $\begin{array}{l}33.91 \\
(1.45)\end{array}$ & $\begin{array}{l}59.45 \\
(1.84)\end{array}$ & $\begin{array}{c}6.04 \\
(0.11)\end{array}$ & $\begin{array}{l}55.25 \\
(0.22)\end{array}$ & $\begin{array}{c}4.90 \\
(0.07)\end{array}$ & $\begin{array}{c}1.73 \\
(0.26)\end{array}$ & $\begin{array}{l}38.13 \\
(0.56)\end{array}$ & $\begin{array}{l}23.80 \\
(0.55)^{\mathrm{c}}\end{array}$ \\
\hline & $300^{\circ} \mathrm{C}$ & $\begin{array}{c}3.24 \\
(0.94)\end{array}$ & $\begin{array}{l}32.22 \\
(2.58)\end{array}$ & $\begin{array}{l}60.97 \\
(1.02)\end{array}$ & $\begin{array}{c}6.26 \\
(0.67)\end{array}$ & $\begin{array}{l}54.32 \\
(0.03)\end{array}$ & $\begin{array}{c}4.95 \\
(0.06)\end{array}$ & $\begin{array}{c}1.76 \\
(0.15)\end{array}$ & $\begin{array}{l}38.98 \\
(0.18)\end{array}$ & $\begin{array}{l}23.62 \\
(0.19)^{\mathrm{c}}\end{array}$ \\
\hline \multirow{4}{*}{$\begin{array}{c}\text { Sweet } \\
\text { sorghum } \\
\text { bagasse }\end{array}$} & raw & $\begin{array}{c}9.29 \\
(0.00)\end{array}$ & $\begin{array}{l}20.32 \\
(0.04)\end{array}$ & $\begin{array}{l}76.35 \\
(0.24)\end{array}$ & $\begin{array}{c}3.28 \\
(0.23)\end{array}$ & $\begin{array}{l}40.32 \\
(0.25)\end{array}$ & $\begin{array}{c}5.42 \\
(0.07)\end{array}$ & $\begin{array}{c}1.22 \\
(0.08)\end{array}$ & $\begin{array}{l}53.06 \\
(0.24)\end{array}$ & $\begin{array}{c}16.45 \\
(0.30)^{\mathrm{a}}\end{array}$ \\
\hline & $250^{\circ} \mathrm{C}$ & $\begin{array}{c}5.51 \\
(1.43)\end{array}$ & $\begin{array}{l}29.60 \\
(2.08)\end{array}$ & $\begin{array}{l}68.36 \\
(1.70)\end{array}$ & $\begin{array}{c}4.03 \\
(0.37)\end{array}$ & $\begin{array}{l}53.96 \\
(1.79)\end{array}$ & $\begin{array}{c}5.05 \\
(0.23)\end{array}$ & $\begin{array}{c}0.94 \\
(0.02)\end{array}$ & $\begin{array}{l}40.06 \\
(2.01)\end{array}$ & $\begin{array}{c}20.09 \\
(0.87)^{\mathrm{b}}\end{array}$ \\
\hline & $275^{\circ} \mathrm{C}$ & $\begin{array}{c}3.83 \\
(0.42)\end{array}$ & $\begin{array}{l}39.68 \\
(0.98)\end{array}$ & $\begin{array}{l}55.68 \\
(0.29)\end{array}$ & $\begin{array}{l}4.60 \\
(0.43)\end{array}$ & $\begin{array}{l}54.48 \\
(3.47)\end{array}$ & $\begin{array}{c}4.58 \\
(0.53)\end{array}$ & $\begin{array}{c}0.93 \\
(0.10)\end{array}$ & $\begin{array}{l}40.02 \\
(3.10)\end{array}$ & $\begin{array}{l}23.43 \\
(1.01)^{\mathrm{c}}\end{array}$ \\
\hline & $300^{\circ} \mathrm{C}$ & $\begin{array}{c}4.37 \\
(0.75)\end{array}$ & $\begin{array}{l}51.50 \\
(0.07)\end{array}$ & $\begin{array}{l}45.29 \\
(0.17)\end{array}$ & $\begin{array}{c}5.85 \\
(0.29)\end{array}$ & $\begin{array}{l}59.30 \\
(3.64)\end{array}$ & $\begin{array}{c}4.56 \\
(0.18)\end{array}$ & $\begin{array}{c}0.92 \\
(0.06)\end{array}$ & $\begin{array}{l}35.23 \\
(2.88)\end{array}$ & $\begin{array}{l}26.88 \\
(0.89)^{d}\end{array}$ \\
\hline
\end{tabular}

*The oxygen contents were obtained from difference, assuming sulfur content was negligible.

**There was no significant difference at $5 \%$ level with the same labeled letter. 
Table 2. The major compounds of liquid product (oil fraction and aqueous fraction) from sorghum torrefaction

\begin{tabular}{|c|c|c|c|c|c|c|}
\hline \multirow[b]{2}{*}{ compounds } & \multicolumn{3}{|c|}{ Energy sorghum } & \multicolumn{3}{|c|}{ Sweet sorghum bagasse } \\
\hline & $250{ }^{\circ} \mathrm{C}$ & $275^{\circ} \mathrm{C}$ & $300{ }^{\circ} \mathrm{C}$ & $250{ }^{\circ} \mathrm{C}$ & $275^{\circ} \mathrm{C}$ & $300{ }^{\circ} \mathrm{C}$ \\
\hline Oil fraction & \multicolumn{6}{|c|}{ area $\%$} \\
\hline ketones & 13.14 & 13.22 & 1.05 & 4.10 & 4.14 & 8.51 \\
\hline 2,3-butanedione & 1.29 & 2.26 & 1.05 & 0.87 & 0.81 & 1.63 \\
\hline 2-propanone, 1-hydroxy- & 2.89 & 4.82 & - & 1.05 & 0.71 & 2.71 \\
\hline 1-hydroxy-2-butanone & 5.27 & 3.25 & - & - & - & - \\
\hline 2-propanone,1-(acetyloxy)- & 3.69 & 2.89 & - & 2.18 & 2.62 & 4.17 \\
\hline furans & 14.67 & 13.27 & 8.47 & 29.24 & 31.77 & 35.01 \\
\hline furfural & 5.59 & 4.39 & 8.47 & 26.19 & 28.77 & 28.33 \\
\hline 2-furanmethanol & 5.37 & 4.21 & - & 3.05 & - & 4.54 \\
\hline 2-furancarboxaldehyde, 5-methyl- & - & - & - & - & 3.00 & 2.14 \\
\hline $\begin{array}{l}\text { 2-furan,tetrahydro-2- } \\
\text { (methoxymethyl)- }\end{array}$ & - & 4.67 & - & & - & - \\
\hline 2-furanmethanol,tetrahydro-,acetate & 3.71 & - & - & - & - & - \\
\hline phenol derivate & 16.09 & 15.62 & 45.58 & 24.20 & 26.19 & 16.20 \\
\hline phenol & 3.92 & 3.30 & 14.50 & 1.67 & 4.39 & 2.36 \\
\hline phenol, 2-methoxy- & 4.79 & 4.08 & 8.49 & 5.70 & 3.50 & 3.75 \\
\hline phenol, 4-ethyl- & 2.72 & 2.74 & 7.40 & 1.42 & 2.88 & 2.70 \\
\hline phenol, 2-methoxy-4-methyl- & - & - & - & 4.75 & 1.20 & \\
\hline phenol, 4-ethyl-2-methoxy- & 1.49 & 2.11 & 4.49 & 4.34 & 3.09 & 2.18 \\
\hline 2-methoxy-4-vinylphenol & - & - & 4.31 & 1.84 & 4.66 & 2.62 \\
\hline phenol, 2,6-dimethoxy- & 3.17 & 3.39 & 6.39 & 2.02 & 3.08 & 2.59 \\
\hline phenol, 2-methoxy-4-(1-propenyl)- & - & - & - & 2.46 & 1.60 & - \\
\hline acids & 38.21 & 38.72 & 25.17 & 18.09 & 13.74 & 28.94 \\
\hline acetic acid & 38.21 & 30.12 & 12.10 & 12.48 & 11.08 & 19.87 \\
\hline n-hexadecanoic acid & - & 5.19 & 8.30 & 2.25 & 2.66 & 4.07 \\
\hline oleic acid & - & 3.41 & - & - & - & 2.08 \\
\hline cis-vaccenic acid & - & - & 4.77 & 3.36 & - & - \\
\hline others & 3.64 & 3.27 & 9.26 & 7.17 & 11.24 & 4.09 \\
\hline $\begin{array}{l}\text { 1,6;2,3-dianhydro-4-O-acetyl-beta-d- } \\
\text { gulopyranose }\end{array}$ & - & - & 5.46 & - & 4.30 & - \\
\hline benzofuran,2,3-dihydro- & 3.64 & 3.27 & 3.80 & - & 6.94 & 4.09 \\
\hline benzaldehyde,2-methyl- & - & - & - & 3.68 & - & - \\
\hline $\begin{array}{l}\text { 2-(2,2-dimethylcyclopropyl) } \\
\text { thiophene }\end{array}$ & - & - & - & 3.49 & - & - \\
\hline total & 85.75 & 84.10 & 89.53 & 82.80 & 87.08 & 92.75 \\
\hline \multicolumn{7}{|l|}{ Aqueous fraction } \\
\hline alcohols & 10.37 & 4.61 & 3.26 & $n / a$ & 6.2 & $n / a$ \\
\hline 1-propanol & - & - & - & - & 2.91 & - \\
\hline 2,3-butanediol & 3.42 & 2.35 & 3.26 & - & - & - \\
\hline
\end{tabular}




\begin{tabular}{|c|c|c|c|c|c|c|}
\hline 1,2,3-propanetriol, monoacetate & 6.95 & 2.26 & - & - & 3.29 & - \\
\hline aldehydes & $n / a$ & $n / a$ & $n / a$ & 2.28 & $n / a$ & 1.88 \\
\hline acetaldehyde,hydroxy- & - & -- & & 2.28 & - & - \\
\hline acetaldehyde & & & & & & 1.88 \\
\hline acids & 39.73 & 37.22 & 51.55 & 36.33 & 55.85 & 53.08 \\
\hline acetic acid & 39.73 & 37.22 & 51.55 & 36.33 & 55.85 & 53.08 \\
\hline ethers & 2.58 & 2.9 & $n / a$ & $n / a$ & $n / a$ & $n / a$ \\
\hline dimethyl ether & 2.58 & -- & - & - & - & - \\
\hline acetic acid, pentyl ester & - & 2.9 & - & - & - & - \\
\hline ketones & 7.25 & 12.05 & 5.1 & 1.73 & 4.48 & 3.1 \\
\hline 2-propanone, 1-hydroxy- & 4.52 & 8.27 & 2.39 & - & 2.07 & - \\
\hline 1-hydroxy-2-butanone & 2.73 & 1.46 & 2.71 & 1.73 & 1.19 & 1.89 \\
\hline 2,3-butanedion & - & 2.32 & - & - & 1.22 & 1.21 \\
\hline furans & 1.92 & 0.82 & 2.22 & 9.96 & 10.46 & 13.21 \\
\hline furfural & - & - & - & 5.24 & 7.78 & 10.62 \\
\hline 2-furanmethanol & 1.92 & 0.82 & 2.22 & 1.08 & - & - \\
\hline $\begin{array}{l}\text { 2-furancarboxaldehyde, 5- } \\
\text { (hydroxymethyl)- }\end{array}$ & - & - & - & 3.64 & 2.68 & 2.59 \\
\hline amides & 11.42 & 4.63 & $n / a$ & 3.19 & $n / a$ & 6.05 \\
\hline 1,3-butanediamine & 8.53 & - & - & - & - & - \\
\hline nitroacetamide & & 2.07 & & & & \\
\hline 1,3-propanediamine, N-methyl- & 2.89 & 2.56 & - & 3.19 & - & 6.05 \\
\hline heterocyclic compounds & $n / a$ & 4.74 & $n / a$ & $n / a$ & $n / a$ & 4.15 \\
\hline sugar derivate & $n / a$ & $n / a$ & $n / a$ & 16.81 & $n / a$ & $n / a$ \\
\hline carbamidine & $n / a$ & $n / a$ & $n / a$ & $n / a$ & 2.72 & $n / a$ \\
\hline total & 73.27 & 66.97 & 62.13 & 70.30 & 79.71 & 81.47 \\
\hline
\end{tabular}

n/a: not detected 